\title{
Os poetas e a poesia de Língua Portuguesa: trajetórias e projetos
}

\author{
Raquel Beatriz Junqueira Guimarães* \\ Raquel S. Madanêlo Souza**
}

Comigo, o caso mais recente de incorporação estética foi com relação à poética de Gonçalo M. Tavares. Fiquei vivamente impressionado com os poemas dele, reunidos no volume 1 , e no épico Uma viagem à Índia, e algum tempo depois fiz alguns poemas influenciados por aquela linguagem, tão diferente da minha. Para mim, como poeta, um dos maiores prazeres que tenho é conhecer outras linguagens, cada uma com sua característica, seu temperamento. (Carlos Frederico Manes) ${ }^{1}$

O diálogo criativo entre os poetas de língua portuguesa, como este narrado aqui por Carlos Frederico Manes, poeta carioca, em entrevista concedida a Simone Guerreiro, é fato consumado na história da literatura. Os trânsitos entre projetos literários distintos, expressões nacionais diversas e linguagens particulares possibilitam que lancemos um olhar investigativo para as Literaturas de Língua Portuguesa, tanto para firmar suas proximidades, quanto para registrar suas idiossincrasias. Por motivos como esse é que a revista Scripta do Programa de Pós-graduação em Letras da PUC Minas e do Centro de Estudos luso-afro-brasileiros publica, nesta edição, um dossiê em torno das produções literárias de poetas e da poesia contemporânea de língua portuguesa. Neste número encontram-se artigos,

\footnotetext{
* $\quad$ Pontifícia Universidade Católica de Minas Gerais (PUC Minas). Professora do programa de pós-graduação em Letras

** Universidade Federal de Minas Gerais (UFMG). Professora de Literatura Portuguesa.

1 Trecho da entrevista concedida a Simone Guerreiro, disponível neste número da Revista Scripta.
} 
resenhas e entrevistas que apresentam poetas e suas trajetórias, e que analisam detidamente projetos literários de escritores e de grupos de artistas que se organizam coletivamente. ${ }^{2}$

O leitor encontrará diferentes reflexões sobre as literaturas de Portugal, Brasil, Angola e Moçambique que abordam a poesia e a crítica literária. Nos artigos, verificam-se diversas questões relativas às poesias contemporâneas e aos caminhos estéticos percorridos pelos poetas: a presença de temas como as aproximações entre artes plásticas e Literatura; a presença da Literatura em mídias digitais e os efeitos desse contato; as problematizações sobre as relações entre obras e tópicos canônicos, formas literárias tradicionais e suas releituras na atualidade; considerações sobre as questões de gênero e sobre a presença do corpo no campo dos estudos literários, além de investigações sobre memória e colonialismo em documentários e testemunhos de artistas de Portugal e da África. Pelos artigos aqui publicados pode-se perceber alguns percursos da crítica literária, que tanto se concentra em teorias dos estudos poéticos, próprios da Teoria da Literatura, como desliza para interfaces com a Filosofia e a Psicanálise.

No conjunto de trabalhos presentes neste dossiê, pode-se notar o que se considera uma tendência no campo dos estudos literários: o interesse da crítica pela produção feminina. São muitos os trabalhos que se dedicam a projetos literários e artísticos de diferentes escritoras.

Embora o dossiê esteja organizado por regiões falantes da língua portuguesa Europa, África e América, optamos nesta apresentação por evidenciar aproximações temáticas entre os poetas dos diferentes países de Língua Portuguesa aqui representados: Portugal, Moçambique, Angola e Brasil.

2 Deve-se registrar que a ideia deste número nasceu de atividades conjuntas realizadas entre o Centro de Estudos luso-afrobrasileiros (PUC Minas) e o Centro de Estudos Portugueses (FALE/UFMG) 
No artigo de Ida Alves e Beatriz Machado Fonseca, investigam-se as cenas de escrita e leitura figuradas nas produções poéticas e críticas presentes na revista contemporânea Telhados de vidro, dirigida pelos poetas Inês Dias e Manuel de Freitas. O posicionamento crítico e editorial de Freitas é ainda tematizado em outro trabalho, de Julia Telésforo Osório, que aborda a antologia Poetas sem qualidades e seu polêmico prefácio intitulado "O tempo dos puetas". Outro autor português da atualidade, que iniciou suas publicações nos anos 90 do século XX, é Daniel Jonas, cujos versos são abordados aqui em dois textos: o primeiro deles, de autoria de Silvana Pessôa, analisa a écfrase como recurso poético que permite articular as relações entre literatura e artes plásticas. No segundo estudo, de Roberto Bezerra de Menezes, a poesia de Jonas é justaposta à de Paulo Henriques Britto, em uma análise comparativa que aponta para as diferenças entre as reflexões metapoéticas dos autores em torno do soneto.

Os projetos literários de Gonçalo Tavares e Herberto Helder são colocados em questão por Ewa A. Łukaszyk, Maria Isabel Bordini e Mariana Pereira Guida. As duas primeiras examinam alguns aspectos da retomada do modelo da epopeia camoniana realizada pelo escritor Gonçalo M. Tavares, enquanto Mariana Pereira Guida analisa o mito de Orfeu na obra de Herberto Helder, incidindo sobre aspectos da finitude e da metamorfose no projeto herbertiano.

Entre os trabalhos que tematizam a condição feminina está, entre os estudos dedicados a autores portugueses, o artigo de Tatiana Pequeno, que investiga as questões de gênero e sexualidade na produção da escritora, filha de mãe portuguesa e pai belga, Bénédicte Houart. 
As poéticas das escritoras são ainda abordadas em vários artigos da Literatura Brasileira. Rafael Quevedo examina as metáforas da navegação na lírica de autoria feminina, com destaque para as escritoras Ana Cristina César (1979), Orides Fontela (1983), Neide Archanjo (1984), Maria Lúcia dal Farra (2011) e Hilda Hilst (1989). Essa última, inclusive, tem sua poesia analisada em outro trabalho, intitulado "Casa da Noite: a morada da poesia de Hilda Hilst", em que Vitor Hugo Luís Geraldo e Enivalda Nunes Freitas e Souza analisam as imagens da noite em um livro da escritora. Jailma Garcia analisa os espaços urbanos na poesia de Marília Garcia; já no texto que versa sobre as vozes de mulheres negras, Elaine Correia de Oliveira e Francine Weiss Ricieri abordam os saraus e slams em São Paulo; enquanto Fabiana Oliveira de Jesus se detém na abordagem das representação do corpo negro da mulher nos livros de poemas da escritora e artista Maria Tereza. Fechando a série de artigos sobre escritoras brasileiras, Eider Madeiros, Letícia Simões Velloso Schuler e Hermano de França Rodrigues realizam a leitura de um poema da escritora carioca Stela do Patrocínio, em uma proposta de aproximação entre Literatura e Psicanálise.

No campo das relações entre a literatura e as mídias digitais, o texto de Débora Keppi Deicke e Vinícius Pereirapropõe uma discussão sobre o conceito de materialidade na obra do ciberpoeta Rui Torres. E seguindo a senda das reflexões sobre obras de escritores portugueses do século XX, o estudo de Vinícius Victor Araujo Barros expõe alguns aspectos da guerra colonial, a partir da poesia de caráter testemunhal dos escritores Manuel Alegre e Fernando Assis Pacheco. 
Adentrando nas reflexões sobre as artes nos países de língua portuguesa, temos a investigação de Aparecida de Fátima Bueno sobre aspectos do colonialismo e do salazarismo, por meio da análise de alguns documentários da angolana Diana Andringa. Já o artigo de Luciana Brandão Leal apresenta a lírica do escritor Luís Carlos Patraquim, destacando, não a vertente já tradicionalmente vinculada a questões pós-coloniais em obras de escritores africanos, mas focalizando o amor e o erotismo na escrita do poeta moçambicano.

Quanto à produção literária brasileira, para além das investigações em torno das poéticas das escritoras, pode-se ler o artigo que encerra o dossiê no qual Iouchabel S. de F. Falcão, Célia Maria Domingues da Rocha Reis e Danilo Barcelos analisam um poema do escritor paulistano Santiago Vilela Marques, por meio da filosofia heideggeriana.

$\mathrm{O}$ volume se completa com uma seção livre, as resenhas e as entrevistas. Na seção livre, os trabalhos não se dedicam à obra de poetas, mas se entregam à análise de contos e romances. Frederico Dias Rosa Alves Teixeira, Flávia Maurício da Rocha Fontes e Priscila Campolina de Sá Campello trazem à cena contos de Marcela Serrano e de Teolinda Gersão, para debaterem questões relativas às dimensões do corpo e do feminino. A literatura britânica está presente a partir da preocupação de Luiz Fernando Ferreira Sá, que se detém em romances de Ian McEwan (2001), Jeanette Winterson (1985) e Hilary Mantel (2012) para discutir o interesse pela coleção na ficção britânica contemporânea.

As três resenhas abordam obras da Literaturas de língua portuguesa e põem em destaque poetas como o mineiro Jacques Fux, o paulista Juliano Garcia Pessanha e o português Gonçalo 
Manuel Tavares. Nas entrevistas, Simone Guerreiro conversa com o poeta Carlos Frederico Manes, com quem desenvolve reflexão importante sobre a literatura como resistência; e Edneia Rodrigues Ribeiro entrevista a filha de João Cabral de Melo Neto, a escritora Inez Cabral, que fala de sua relação com o pai e sua emoção ao saber da existência de um poema dedicado a ela.

Boa leitura a todos.

As organizadoras 